\title{
Effect of Macrophytes on Flow Conditions and Deposition of Suspended Particles in Small Streams: an Experimental Study Using Artificial Vegetation
}

\section{Impact des macrophytes sur les conditions d'écoulement et sur la sédimentation des particules en suspension dans les petits cours d'eau : une étude expérimentale utilisant de la végétation artificielle}

\author{
Delphine C. Rolland, Jacques Haury, Pierre Marmonier et Yvan Lagadeuc
}

Volume 28, numéro 3, 2015

Reçu le 6 juin 2014, accepté le 26 août 2015

URI : https://id.erudit.org/iderudit/1034012ar

DOI : https://doi.org/10.7202/1034012ar

Aller au sommaire du numéro

Éditeur(s)

Université du Québec - INRS-Eau, Terre et Environnement (INRS-ETE)

ISSN

1718-8598 (numérique)

Découvrir la revue

Citer cet article

Rolland, D. C., Haury, J., Marmonier, P. \& Lagadeuc, Y. (2015). Effect of Macrophytes on Flow Conditions and Deposition of Suspended Particles in Small Streams: an Experimental Study Using Artificial Vegetation. Revue des sciences de l'eau / Journal of Water Science, 28(3), 231-245.

https://doi.org/10.7202/1034012ar
Résumé de l'article

La présence de macrophytes dans le lit d'un cours d'eau est souvent déterminante, car elle influence les conditions d'écoulement. En effet, les macrophytes sont souvent considérés comme des organismes ingénieurs qui modifient l'environnement aquatique par leur structure physique et leur activité métabolique. Le rôle des macrophytes aquatiques sur la sédimentation des matières en suspension a été étudié dans trois petits cours d'eau peu profonds en Bretagne (France). Les expériences de terrain ont été effectuées en avril 2007 en utilisant des macrophytes artificiels ressemblant à Callitriche et des pièges à sédiments cylindriques positionnés dans les cours d'eau. Les caractéristiques hydrodynamiques (profil de vitesse, taux de décroissance de la vitesse, turbulences), le taux de sédimentation, les caractéristiques granulométriques et le contenu en matière organique particulaire des sédiments piégés dans les macrophytes ont été mesurés et comparés aux témoins. Les macrophytes artificiels se sont comportés comme des pièges à sédiments en modifiant localement les paramètres hydrodynamiques. La sédimentation de particules fines dans les macrophytes atteint des valeurs maximales lorsque la vitesse du courant peut être efficacement ralentie, c'est-à-dire lorsque la vitesse initiale est faible (inférieur à $0,5 \mathrm{~m} \cdot \mathrm{s}^{-1}$ ) et la profondeur suffisamment faible pour que la plante occupe tout le volume de la colonne d'eau. Dans le cas contraire, la turbulence générée au voisinage des macrophytes induit une resuspension des particules fines et uniquement les particules grossières sont piégées. Cette étude montre l'importance des valeurs de seuil à l'échelle locale et l'effet très dynamique des macrophytes sur les caractéristiques d'écoulement dans les petits cours d'eau peu profonds. 


\section{EFFECT OF MACROPHYTES ON FLOW CONDITIONS AND}

\section{DEPOSITION OF SUSPENDED PARTICLES IN SMALL STREAMS: AN EXPERIMENTAL STUDY USING ARTIFICIAL VEGETATION}

Impact des macrophytes sur les conditions d'écoulement et sur la sédimentation des particules en suspension dans les petits cours d'eau : une étude expérimentale utilisant de la végétation artificielle

DELPHINE C. ROLLAND ${ }^{1,3,4 *}$ JACQUes HAURY', PIERRE MARMONIER², YVAN LAGADEUC 3,4

${ }^{1}$ ESP, Agrocampus Ouest, 65 rue de Saint Brieuc, 35000 Rennes, France

${ }^{2}$ UMR-CNRS 5023 LEHF, Université de Lyon, 43 boulevard du 11 Novembre 1918, 69622 Villeurbanne, France

${ }^{3}$ UMR-CNRS 6553 ECOBIO, Université de Rennes 1, Campus de Beaulieu, 35042 Rennes, France

${ }^{4}$ OSUR, Université de Rennes 1, Campus de Beaulieu, 35042 Rennes, France

Reçu le 6 juin 2014, accepté le 26 août 2015

\section{ABSTRACT}

Aquatic macrophytes are often the dominant element that influences flow conditions within streams, and are often considered as ecosystem engineers that modify their aquatic environment as a result of their physical structure and metabolic activity. The role of aquatic macrophytes on suspended matter sedimentation was studied in three shallow low-order streams in Brittany (North-western France). Field experiments were carried out in April 2007 using Callitrichelike artificial macrophytes and cylindrical sediment traps dug into the channels. Hydrodynamic characteristics (velocity profile, percentage of velocity decrease and turbulence), volume of trapped sediment, particle size characteristics, and total organic matter content were measured within the macrophytes and compared with the control traps. The aquatic macrophytes operated as sediment traps by modifying the local hydrodynamic parameters. Sedimentation of fine suspended particles within the macrophytes reached maximum values when the velocity was significantly reduced, i.e. when the initial velocity was low (less than $0.5 \mathrm{~m} \cdot \mathrm{s}^{-1}$ ) and the depth shallow enough for the plant to occupy the entire volume of the column water. Conversely, turbulence was generated around the macrophyte stands, which induced the resuspension of fine particles and only coarse particles were trapped. This study shows the importance of threshold values at the local scale and the highly dynamic effect of macrophytes on flow characteristics.

Key Words: Hydrodynamics, macrophytes, sedimentation, stream, velocity. 


\section{RÉSUMÉ}

La présence de macrophytes dans le lit d'un cours d'eau est souvent déterminante, car elle influence les conditions d'écoulement. En effet, les macrophytes sont souvent considérés comme des organismes ingénieurs qui modifient l'environnement aquatique par leur structure physique et leur activité métabolique. Le rôle des macrophytes aquatiques sur la sédimentation des matières en suspension a été étudié dans trois petits cours d'eau peu profonds en Bretagne (France). Les expériences de terrain ont été effectuées en avril 2007 en utilisant des macrophytes artificiels ressemblant à Callitriche et des pièges à sédiments cylindriques positionnés dans les cours d'eau. Les caractéristiques hydrodynamiques (profil de vitesse, taux de décroissance de la vitesse, turbulences), le taux de sédimentation, les caractéristiques granulométriques et le contenu en matière organique particulaire des sédiments piégés dans les macrophytes ont été mesurés et comparés aux témoins. Les macrophytes artificiels se sont comportés comme des pièges à sédiments en modifiant localement les paramètres hydrodynamiques. La sédimentation de particules fines dans les macrophytes atteint des valeurs maximales lorsque la vitesse du courant peut être efficacement ralentie, c'est-à-dire lorsque la vitesse initiale est faible (inférieur à $0,5 \mathrm{~m} \cdot \mathrm{s}^{-1}$ ) et la profondeur suffisamment faible pour que la plante occupe tout le volume de la colonne d'eau. Dans le cas contraire, la turbulence générée au voisinage des macrophytes induit une resuspension des particules fines et uniquement les particules grossières sont piégées. Cette étude montre l'importance des valeurs de seuil à l'échelle locale et l'effet très dynamique des macrophytes sur les caractéristiques d'écoulement dans les petits cours d'eau peu profonds.

\section{Mots-clés : Hydrodynamisme, macrophytes, ruisseau, sédimentation, vitesse.}

\section{INTRODUCTION}

Changes in land cover induced by agriculture intensification have a major effect on aquatic communities (HARDING et al., 1998). Sediment yield linked to erosion rate has been greatly increased by modifications in watershed soil use (BRAMLEY and ROTH, 2002; COLLINS and WALLING, 2007; KOSMAS et al., 1997; LEFRANÇOIS et al., 2007). Several consequences on aquatic ecosystems have been highlighted: a decrease in light penetration and primary production, a decrease in the benthic habitat heterogeneity, clogging of the hyporheic zone (GAYRAUD et al., 2002 and references therein) with decreases in the oxygenation of bottom sediments, a reduction in density and diversity of aquatic invertebrates (GAYRAUD et al., 2002 and references therein; HANCOCK, 2002) and a reduction of spawning habitats for salmonids (LEFEBVRE et al., 2004; SMITH and DRAGOVITCH, 2008). The impact of increased suspended sediment load is a relevant issue in Brittany where the level of agricultural activity is one of the highest in France and where clogging of the hyporheic zone by fine inorganic particles remains a concern (LEFEBVRE et al., 2004).

The major factor that controls the deposition of suspended matter on the stream bed is turbulence created through bottom shear stress (KOZERSKI and LEUSCHNER, 1999; NEPF, 1999). This turbulence is directly linked to the water velocity and decreases when the stream water flows through patches of submerged vegetation (HAMILTON and MITCHELL, 1996; KRISTENSEN et al., 1992; SCHULTZ et al., 2003; WHARTON et al., 2006). The decrease in turbulence reduces sediment re-suspension by water flow (FONSECA and CAHALAN, 1992; GREEN, 2005 and references therein). As a result, fine particles $(<1 \mathrm{~mm})$ are more likely to settle in and just downstream of macrophyte stands (SCHULTZ et al., 2003), suspended matter sedimentation is enhanced and water turbidity decreases (COTTON et al., 2006; HORPPILA and NURMINEN, 2003; MADSEN et al., 2001; PETTICREW and KALFF, 1992). Given that such modifications could cause geomorphological and ecological changes, macrophytes act as "ecosystem engineers" within stream channels (GIBBS et al., 2012).

Most studies focusing on the impact of submerged macrophytes on flow conditions and deposition of suspended sediments have been carried out using Ranunculus sp. (COTTON et al., 2006; HEPPELL et al., 2009; HORPPILA and NURMINEN, 2003; WHARTON et al., 2006) and to a lesser extent, Sparganium sp. (NADEN et al., 2006; SANDJENSEN, 1998), Elodea sp. or Callitriche sp. (SAND-JENSEN, 1998; SAND-JENSEN and MEBUS, 1996; SAND-JENSEN and PEDERSEN, 1999). Some species of Callitriche found in Brittany streams such as Callitriche hamilata and Callitriche obtusangula are quite widespread and can be found submerged in the riffles, especially during periods of low water (DANIEL and HAURY, 1996; HAURY and BAGLINIÈRE, 1996). These stands, classified as broad-leaved types with high shoot density, may reduce the current velocity and trap sediments (CLARKE, 2002; HAURY and GOUESSE AÏDARA, 1999).

Most studies about the impact of macrophytes on flow have been carried out to determine the potential for them to cause flooding (GREEN, 2005 and references therein). The link between the hydrodynamic effect and possible trapping of fine particles has been less extensively developed (e.g. PETTICREW, 1992; SAND-JENSEN, 1998; SCHULTZ et al., 2003; WHARTON et al., 2006). Moreover, many vegetative resistance models have been developed based on physical theory, and data for their development have mainly been obtained from experiments in flumes (e.g. CAROLLO 
et al., 2002; COOPER et al., 2007; NEPF, 1999; STONE and SHEN, 2002). Current theoretical models cannot be applied to natural streams, where the flow and the geomorphological conditions are much more complicated. Empirical models have also been developed from data collected under natural conditions. These models have been mainly designed for uniform stands of grass-like vegetation and cannot be transposed to species that have a more complicated shape, such as Callitriche sp.

The overall objective of the present study was to define the interaction among individual bundles of Callitrichelike submersed macrophytes, water movement and sediment dynamics at a local scale in three low-order streams in Brittany whose watersheds differ in land cover and morphometry. We studied changes in hydrodynamic characteristics downstream from vegetation stands and we measured the total volume, organic matter content and particle size composition of the stored sediments for different discharges and water depth conditions. This original field-based experiment was carried out using plastic vegetation stands, to avoid any biological effects of the macrophytes and to control the geometry of the macrophyte beds. The impact of macrophytes on water movement (velocity, turbulence, vertical profile shapes within the water column) has been mostly described in flumes. Our experiments demonstrated the effect of high geomorphological variability at small scales within agricultural streams.

\section{MATERIALS AND METHODS}

\subsection{Study area}

The study was carried out at two sites in France: the Oir River watershed, an Environmental Research Observatory (ORE) of the National Institute of Agronomical Research (INRA), in Lower Normandy $\left(48^{\circ} 6^{\prime} \mathrm{N}, 1^{\circ} 3^{\prime} \mathrm{W}\right)$, and the Chênelais River watershed in the Long Term Socio-Ecological Research site of the Centre National de la Recherche Scientifique (CNRS) in Brittany $\left(48^{\circ} 4^{\prime} \mathrm{N}, 1^{\circ} 3^{\prime} \mathrm{W}\right)$. Both sites have a temperate oceanic climate with a total annual rainfall of $900 \pm 170 \mathrm{~mm}$ (mean \pm SD from 1997 to 2007), a mean annual temperature of $11.7 \pm 0.8^{\circ} \mathrm{C}$ (mean \pm SD from 1997 to 2007), a low-water period from June to November and a high-flow period from December to May.

In the Oir watershed $\left(86 \mathrm{~km}^{2}\right)$, the stream substratum is Brioverian schist with stream bottom sediment consisting mainly of fine gravel and fine sand. In this area, the agriculture is characterized by dairy farming and the watershed land-cover is dominated by grassland and crop fields (maize and other grain crops). Two streams were studied in the Oir watershed:
1) Moulinet (a second-order stream, designated MOU), with discharges that range between 20 and $70 \mathrm{~L} \cdot \mathrm{s}^{-1}$ and a watershed land-cover equally distributed between grassland and cultivated fields (Table 1) and 2) Violettes (a second-order stream, designated VIO), with discharges ranging between 10 and $50 \mathrm{~L} \cdot \mathrm{s}^{-1}$ and a watershed land-cover dominated by grassland (close to $60 \%$, Table 1). Both streams flow across a plateau with gentle slopes, and an average altitude of about $100 \mathrm{~m}$. The Moulinet watershed covers $4.53 \mathrm{~km}^{2}$, whereas the Violettes watershed covers $2.24 \mathrm{~km}^{2}$.

In the Chênelais watershed $\left(70 \mathrm{~km}^{2}\right)$, the Petit Hermitage (a first-order stream, designated HER) flows over a granitic substratum with bottom sediment consisting of fine gravel and coarse sand and has discharges that range between 5 and $10 \mathrm{~L} \cdot \mathrm{s}^{-1}$. The watershed (Table 1 ) is entirely covered by a mixed forest of beech (Fagus sylvaticus) and oak (Quercus pedunculata).

Besides the different land covers, these three streams were also chosen because they offer different conditions of stream flow and depth during the study period (Table 1): Moulinet and Violettes showed similar surface water velocities $(0.4-0.7$ and $0.4-0.6 \mathrm{~m} \cdot \mathrm{s}^{-1}$, respectively), which were higher than Petit Hermitage $\left(0.1-0.2 \mathrm{~m} \cdot \mathrm{s}^{-1}\right)$. Water depth was highest in Moulinet $(14.2-36.3 \mathrm{~cm})$, intermediate in Violettes $(8.1-21.8 \mathrm{~cm})$ and lowest in Petit Hermitage $(6-13.1 \mathrm{~cm})$.

\subsection{Discharge}

Moulinet and Violettes outlets were equipped with sensors measuring the turbidity (NTU), the flow velocity $\left(\mathrm{m} \cdot \mathrm{s}^{-1}\right)$ and the height $(\mathrm{cm})$ of stream water. Suspended sediment concentrations (SSC; mg. $\mathrm{L}^{-1}$ ) were then estimated from turbidity (measured by APC-TU turbidimeter, Ponselle) by using calibration curves (BIRGAND et al., 2004). Discharge, i.e. the volume rate of water flow $\left(\mathrm{Q}_{\mathrm{w}} ; \mathrm{L} \cdot \mathrm{s}^{-1}\right)$, was calculated by combining height, measured by ultrasound, and velocity, measured by Doppler-effect, both using a Starflow device. The Starflow was placed in the middle of a wooden flume built in the channel bed (BIRGAND et al., 2005). Water turbidity, velocity and height were measured every $30 \mathrm{~s}$ and averaged every $10 \mathrm{~min}$. The mean $\mathrm{Q}_{\mathrm{w}}$ and mean SSC allowed us to calculate the mean suspended sediment discharge $\left(Q_{s} ; \mathrm{g} \cdot \mathrm{s}^{-1}\right)$ for April 2007. Automated equipment was not available in Petit Hermitage, thus $\mathrm{Q}_{\mathrm{w}}$ was estimated at three sites $(\mathrm{H} 1, \mathrm{H} 2$, H3) and six dates (29 March, 3, 10, 17, 24 and 30 April), by multiplying the mean water velocity by the stream cross sectional area. The stream cross sectional area was derived from point measurements of water level and the mean velocity was estimated from velocity measurements along a profile using a micro-helix flow meter Mini Air 2 (accuracy of $\pm 0.04 \mathrm{~m} \cdot \mathrm{s}^{-1}$ ). 
Table 1. Characteristics of Moulinet, Violettes and Petit Hermitage streams and associated replication sites in April 2007. Tableau 1. Caractéristiques des ruisseaux Moulinet, Violettes et Petit Hermitage et de leurs sites réplicas en avril 2007.

\begin{tabular}{|c|c|c|c|c|c|c|c|c|c|}
\hline Land cover (\%) & \multicolumn{3}{|c|}{ Moulinet } & \multicolumn{3}{|c|}{ Violettes } & \multicolumn{3}{|c|}{ Petit Hermitage } \\
\hline $\begin{array}{l}\text { Built-up area } \\
\& \text { roads }\end{array}$ & \multicolumn{3}{|c|}{3.5} & \multicolumn{3}{|c|}{6.5} & \multicolumn{3}{|c|}{0} \\
\hline Forest & \multicolumn{3}{|c|}{11.3} & \multicolumn{3}{|c|}{1.3} & \multicolumn{3}{|c|}{99.8} \\
\hline Cultivated fields & \multicolumn{3}{|c|}{43.2} & \multicolumn{3}{|c|}{30.5} & \multicolumn{3}{|c|}{0} \\
\hline Grasslands & \multicolumn{3}{|c|}{39.5} & \multicolumn{3}{|c|}{56.5} & \multicolumn{3}{|c|}{0.2} \\
\hline \multirow[t]{2}{*}{ Waste lands } & \multicolumn{3}{|c|}{2.6} & \multicolumn{3}{|c|}{5.2} & \multicolumn{3}{|c|}{0} \\
\hline & \multicolumn{9}{|c|}{ Replication sites } \\
\hline Stream properties & M1 & M2 & M3 & V1 & V2 & V3 & H1 & $\mathbf{H} 2$ & H3 \\
\hline $\begin{array}{l}\text { Mean flow velocity } \\
\left(\mathrm{m} \cdot \mathrm{s}^{-1}\right)\end{array}$ & $0.5 \pm 0.1$ & $0.5 \pm 0.1$ & $0.6 \pm 0.1$ & $0.5 \pm 0.1$ & $0.6 \pm 0.1$ & $0.5 \pm 0.1$ & $0.2 \pm 0.1$ & $0.2 \pm 0.1$ & $0.2 \pm 0.1$ \\
\hline Stream bed & $\begin{array}{c}\text { sand } \& \\
\text { gravel }\end{array}$ & $\begin{array}{c}\text { sand \& } \\
\text { gravel }\end{array}$ & $\begin{array}{c}\text { sand } \& \\
\text { gravel }\end{array}$ & sand & sand & sand & $\begin{array}{c}\text { sand } \& \\
\text { gravel }\end{array}$ & $\begin{array}{c}\text { sand \& } \\
\text { gravel }\end{array}$ & $\begin{array}{c}\text { sand } \& \\
\text { gravel }\end{array}$ \\
\hline Depth $(\mathrm{cm})$ & $25.2 \pm 5.1$ & $21.3 \pm 6.1$ & $29.2 \pm 7.1$ & $12.1 \pm 3.0$ & $15.2 \pm 6.6$ & $18.1 \pm 7.6$ & $11.0 \pm 2.1$ & $9.1 \pm 1.2$ & $7.3 \pm 1.3$ \\
\hline Width $(\mathrm{cm})$ & 101 & 118 & 96 & 112 & 105 & 92 & 250 & 227 & 274 \\
\hline
\end{tabular}

\subsection{In situ experiments}

We used artificial macrophytes to control the shape, size and structural complexity of the bundles, making it possible to compare sites while avoiding biological effects (e.g. growth, decay, and organic matter input). Macrophytes were simulated using plastic aquarium plants (Namiba ${ }^{\circledR}$ Plastic Plant, $\mathrm{N}^{\circ}$ 5937; Figure 1), with $40 \mathrm{~cm}$ flexible stems and 20- to 30-mm-long lanceolate leaves. Each bundle of macrophytes was composed of eight stems, fixed together on a thick wooden support $10 \mathrm{~cm}$ long, $4 \mathrm{~cm}$ wide and $1 \mathrm{~cm}$ deep (Figure 1). Because stem flexibility is an important parameter influencing the resistance to flow, preliminary tests were done by comparing the plastic macrophyte flexibility with real macrophyte flexibility in situ. It appeared that the flexibility was similar to an equivalent density of Callitriche sp. when flow was around $30 \mathrm{~L} \cdot \mathrm{s}^{-1}$, and stems and leaves were completely submerged and oriented in the flow direction.

We used polypropylene cylindrical sediment traps dug into the bottom of the stream to measure the rate of deposition of suspended material. Because of the reduced bottom sediment thickness in the studied rivers, we used $10 \mathrm{~cm}$ high traps with the top opening reduced to a $2 \mathrm{~cm}$ diameter hole (height/ diameter ratio of five, consistent with GARDNER, 1985).
In each stream, three sites (Moulinet: M1, M2 and M3; Violettes: V1, V2 and V3; Petit Hermitage: H1, H2 and H3) were selected for sedimentation experiment replicates. Each site was composed of a control setting (a cylindrical trap without macrophytes) and a macrophyte setting (a cylindrical trap dug $20 \mathrm{~cm}$ just downstream from a bundle of plastic macrophytes). The control setting was positioned a few meters upstream from the macrophytes setting (Figure 2). All sites were located in a riffle, with equivalent depths, stream morphometry and bottom substratum (Table 1). The artificial macrophytes were anchored to the stream bed with two aluminium tent pegs fixed to the basal wooden support. The traps and macrophytes were installed on 29 March 2007 and sediments collected inside the 18 traps were sampled each week during April 2007 (3, 10, 17 and 24 April) before the seasonal growth of natural macrophytes.

Velocity profiles in the water column were analyzed by measuring local velocities on 3,10,17 and 24 April inside the artificial macrophytes, using a Mini Air 2 micro-helix flow meter. For a given profile, velocity measurements were made at a regular interval $(3-5 \mathrm{~cm})$ from the surface to the bottom of the water column. 

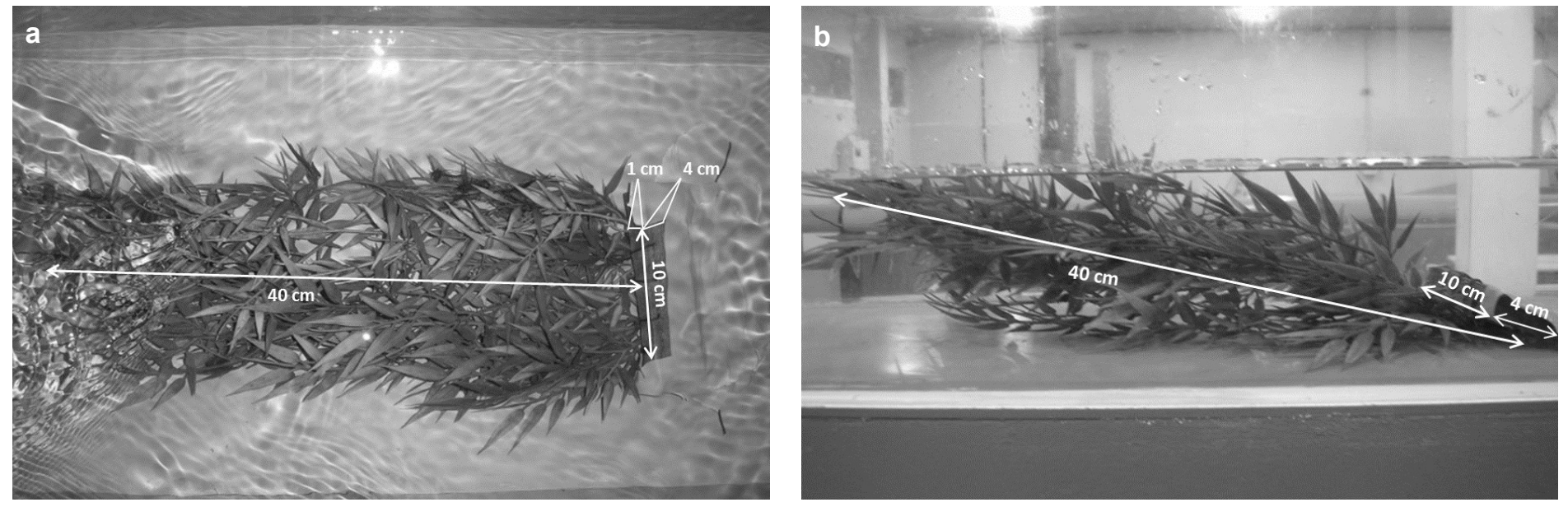

Figure 1. Pictures of the artificial macrophyte design in a hydraulic flume: (a) top view and (b) side view.

Photographies du modèle de conception de macrophyte artificiel en banc hydraulique : (a) vue du dessus et (b) vue latérale.

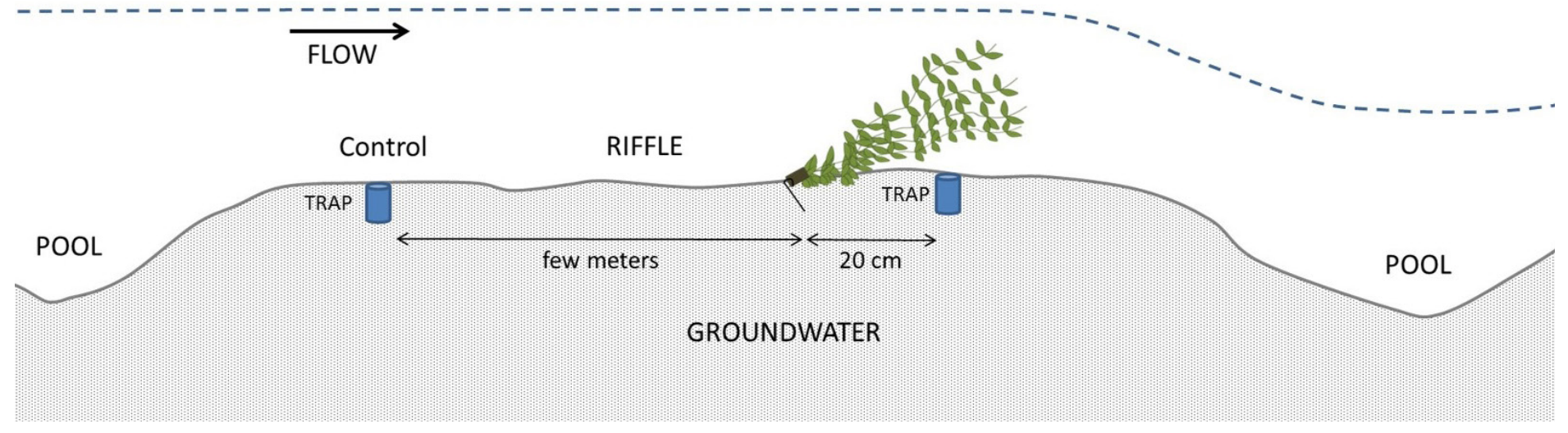

Figure 2. Layout of the experimental device within the three streams. The control trap (without macrophytes) is located a few meters upstream from the trap with macrophytes.

Agencement du dispositif expérimental dans les trois cours d'eau. Le piège contrôle (sans macrophytes) est situé quelques mètres en amont du piège avec macrophytes.

For each date and sampling site, we calculated the Reynolds number $(\mathrm{Re})$ :

$$
\operatorname{Re}=\mathrm{ud} / \mathrm{v}
$$

where $\mathrm{u}$ is the mean water velocity around the considered object (here, the artificial macrophyte), $\mathrm{d}$ is the length of the object (here, $40 \mathrm{~cm}$ ) and $\mathrm{v}$ is the kinematic viscosity of the water, which varies with temperature and pressure (PALMER et al., 2004).

The effect of macrophytes on the flow velocity in each stream and for each replicate was described using three variables: the geometric shape of the velocity profile, the velocity at the water surface $\left(\mathrm{V}_{\mathrm{i}}\right)$ and the percentage of velocity decrease $(\mathrm{V})$ between the surface and the bottom.

\subsection{Laboratory analyses}

The wet volume of trapped sediments (TSV; $\mathrm{cm}^{3}$ ) was measured in the laboratory. After drying for $24 \mathrm{~h}$ at $105^{\circ} \mathrm{C}$ and then mechanical disaggregation, each sample was fractionated into four classes of different particle sizes by sieving: silts and clays $(<50 \mu \mathrm{m})$, fine sand $(50-200 \mu \mathrm{m})$, coarse sand $(200-$ $2000 \mu \mathrm{m}$ ), and gravels (> $2000 \mu \mathrm{m}$; NF standard X31-107). The volume of each class was measured. Particle size was defined by passing a known volume of dry subsample through three stainless steel sieves (Wildco) with different sized meshes (2 $000 \mu \mathrm{m}, 200 \mu \mathrm{m}, 50 \mu \mathrm{m}$ ). The individual volumes of different size class were then calculated as a percentage of the TSV. In this paper, fine sediments are defined as inorganic and organic materials $<200 \mu \mathrm{m}$ in diameter. The total weight of 
organic matter (TOM) was measured by ignition loss ( $4 \mathrm{~h}$ at $550^{\circ} \mathrm{C}$; BRETSCHKO and LEICHTFRIED, 1987) and then calculated as a percentage.

\subsection{Statistical analyses}

Statistics were performed using STATISTICA (STATSOFT INC., 2007). An initial Shapiro-Wilk test indicated that the data for most variables were not normally distributed. The Mann-Whitney non parametric rank sum test was performed to compare two independent groups. Kruskal-Wallis ANOVA on rank tests were used to compare more than two independent groups and then all pairwise multiple comparisons were made using Dunn's method to identify significant differences between groups. Spearman rank order correlation analyses were conducted. The chosen level of significance was $\mathrm{p}<0.05$.

\section{RESULTS}

\subsection{Discharge}

$\mathrm{Q}_{\mathrm{w}}$ during April was significantly higher in Moulinet $\left(55.9-121.0 \mathrm{~L} \cdot \mathrm{s}^{-1}\right)$ than in Violettes $\left(9.5-38.3 \mathrm{~L} \cdot \mathrm{s}^{-1}\right.$; MannWhitney test, $\mathrm{p}=0.03$; Table 2). Such values both correspond to the end of the high flow period. $\mathrm{Q}_{\mathrm{w}}$ was significantly higher (Kruskal-Wallis test, $\mathrm{p}=0.02$ ) at the beginning of the study than during the other weeks in Moulinet. $\mathrm{Q}_{\mathrm{w}}$ during April in
Petit Hermitage was maximal at the beginning of the study (3 April; $15.5 \mathrm{~L} \cdot \mathrm{s}^{-1}$; data not presented) and minimal at the end (24 April; $6.4 \mathrm{~L} \cdot \mathrm{s}^{-1}$; data not presented). Q during April followed the same pattern with significant differences between Moulinet and Violettes (up to three times higher in Moulinet; Mann-Whitney, $\mathrm{p}=0.03$ ) and between dates in Moulinet (up to three times higher the first week; Kruskal-Wallis, $\mathrm{p}=0.04$; Table 2).

\subsection{Effect of macrophytes on flow velocity and hydraulic characteristics}

The velocity profile shapes differed between streams, between dates and between experimental conditions. Five geometric forms were identified among the velocity profiles (Figure 3): 1) A progressive linear decrease from the water surface to a depth of $95 \%$ of the water column, sometimes followed by a strong decrease in the vicinity of the stream bottom, 2) a logarithmic shaped profile, 3) an exponential shaped profile, 4) a sigmoidal shaped profile with small velocity changes at the top and the bottom of the water column, and a strong decrease in the central part of the profile and 5) an abrupt increase at the sub-surface causing a steep inflexion before a progressive decrease. Velocity profiles without macrophytes were mostly characterized by an exponential shape in Moulinet and various shapes in Violettes (logarithmic, sigmoid and exponential; Figure 4) whereas velocity profiles with macrophytes were mostly characterized by a sigmoid shape in Moulinet and a linear shape in Violettes (Figure 4). The velocity profile in Petit Hermitage was always linear, with or without macrophytes.

Table 2. Mean weekly water discharge $\left(Q_{w} ; L \cdot s^{-1}\right)$ and mean weekly suspended sediment discharge $\left(Q_{;} ; g \cdot s^{-1}\right)$ at Moulinet and Violettes outlets in April 2007. Mean \pm standard deviation $(\mathrm{N}=1008)$.

Tableau 2. Moyennes hebdomadaires des débits $\left(Q_{w} ; L \cdot s^{-1}\right)$ et apports sédimentaires $\left(Q ; g \cdot s^{-1}\right)$ mesurés à l'exutoire de Moulinet et Violettes en avril 2007. Moyenne \pm écart-type $(N=1008)$.

\begin{tabular}{lcc}
\hline Properties & \multicolumn{2}{c}{ Streams } \\
\hline & & Moulinet \\
Mean weekly $\mathrm{Q}_{\mathrm{w}}\left(\mathrm{L} \cdot \mathrm{s}^{-1}\right)$ & $103.9 \pm 17.1$ & $26.5 \pm 11.8$ \\
\cline { 2 - 3 } 29 March to 3 April & $77.8 \pm 6.9$ & $22.8 \pm 9.5$ \\
4 to 10 April & $72.9 \pm 3.2$ & $25.6 \pm 7.0$ \\
11 to 17 April & $59.0 \pm 3.1$ & $12.7 \pm 3.2$ \\
18 to 24 April & $60.2 \pm 2.5$ & $16.7 \pm 10.5$ \\
25 to 30 April & & \\
& & \\
Mean weekly $\mathrm{Q}_{\mathrm{s}}\left(\mathrm{g} \cdot \mathrm{s}^{-1}\right)$ & $4.99 \pm 0.65$ & $1.66 \pm 0.55$ \\
30 March to 4 April & $2.11 \pm 0.03$ & $1.06 \pm 0.16$ \\
4 to 10 April & $2.51 \pm 0.41$ & $0.37 \pm 0.16$ \\
11 to 17 April & $1.55 \pm 0.03$ & $1.41 \pm 0.47$ \\
18 to 24 April & $1.70 \pm 0.09$ & \\
25 to 30 April & & \\
\hline
\end{tabular}




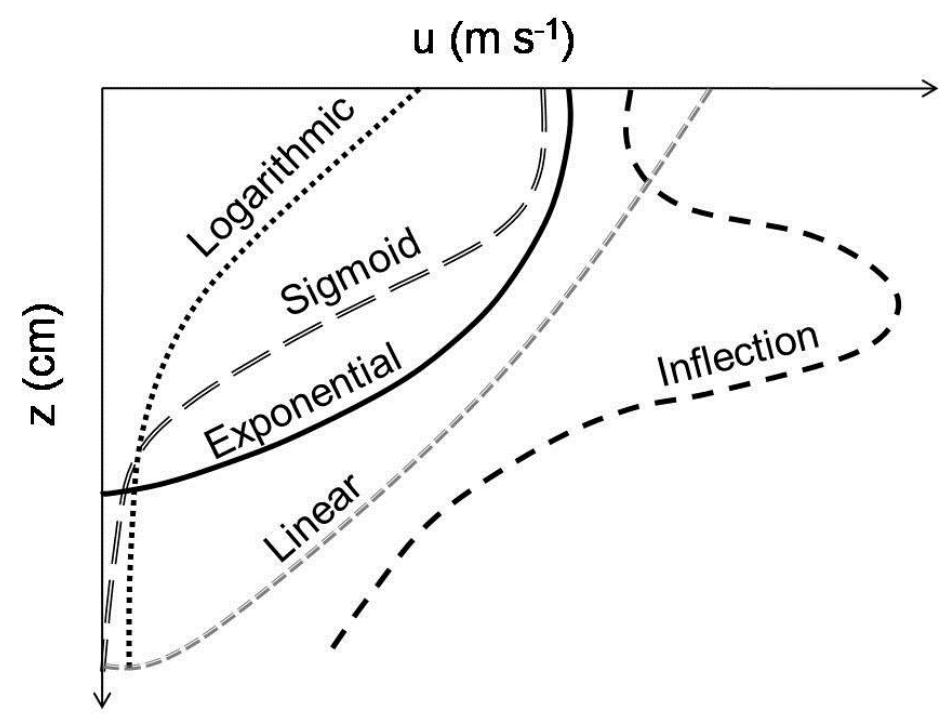

Figure 3. Different shapes of velocity profiles identified in Moulinet, Violettes and Petit Hermitage streams. Différentes formes de profils de vitesse identifiées dans les ruisseaux Moulinet, Violettes et Petit Hermitage.
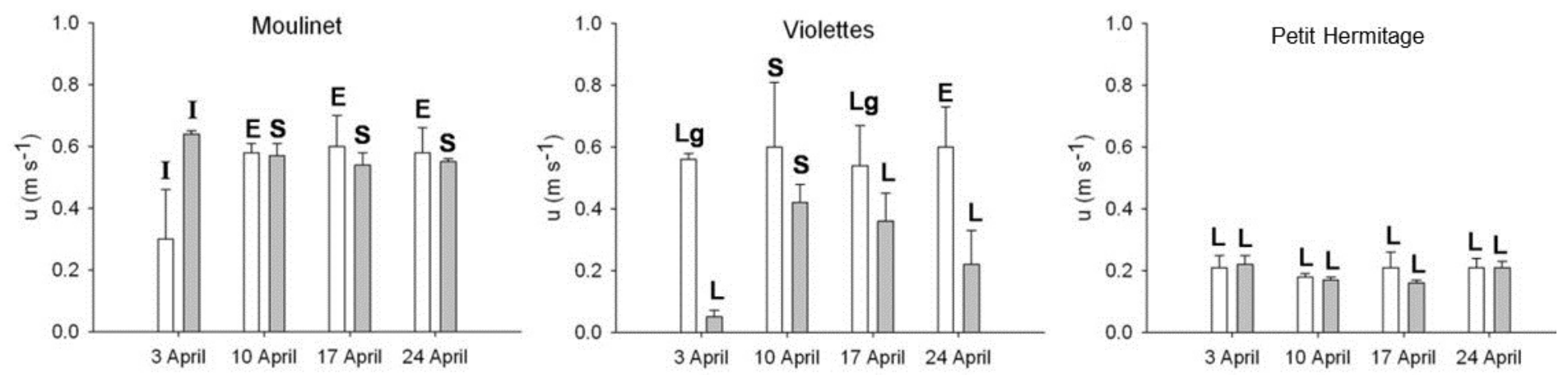

Figure 4. Comparison of surface water velocity with (grey) or without (white) artificial macrophytes (mean \pm standard deviation of the replicates) and dominant shape of velocity profile observed in Moulinet, Violettes and Petit Hermitage streams (I: Inflexion, E: Exponential, S: Sigmoidal, Lg: Logarithmic, L: Linear).

Comparaison des vitesses de surface avec (gris) ou sans (blanc) macrophyte artificiel (moyenne \pm écart-type des réplicas) et formes dominantes de profil de vitesses observées pour les ruisseaux Moulinet, Violettes et Petit Hermitage (I : Inflexion, E : Exponentiel, $S$ : Sigmoïde, Lg : Logarithmique, L : Linéaire).

$\mathrm{V}_{\mathrm{i}}$ did not differ between the control and with macrophytes in Moulinet except at the beginning of the study on 3 April (more than two times higher with macrophytes), when the $\mathrm{Q}_{\mathrm{w}}$ was higher. $\mathrm{V}_{\mathrm{i}}$ was significantly lower (Mann-Whitney, $\mathrm{p}<0.001)$ in the presence of macrophytes in Violettes on each date and did not differ between the control and with macrophytes in Petit Hermitage (Figure 4).

The percentage of $\mathrm{V}_{\mathrm{r}}$ between the surface and the bottom of the water column was significantly higher with macrophytes in the three streams (Mann-Whitney, $\mathrm{p}<0.001$; Table 3).
$\mathrm{V}_{\mathrm{r}}$ was in the range $80-100 \%$ with macrophytes, whereas without macrophytes it reached a maximum of $43.9 \%, 70.5 \%$ and $43.2 \%$ in Moulinet, Violettes and Petit Hermitage, respectively. However, the macrophyte resistance was more effective in Moulinet and Petit Hermitage than in Violettes.

Re was characteristic of highly turbulent conditions and varied from $5050 \pm 1340$ within the macrophytes, to $12500 \pm 6530$ at the control sites and $120000 \pm 64300$ around the artificial macrophytes. Differences between streams and dates were not significant. 


\subsection{Quantity of trapped sediments}

TSV did not vary significantly during the study period but varied between streams (Kruskal-Wallis, $\mathrm{p}=0.023$; Table 4). In Moulinet, TSV varied from 75 to $205 \mathrm{~cm}^{3}$ (with a mean of $156 \pm 35 \mathrm{~cm}^{3}$ ), with generally high standard deviations and no significant difference between control traps and traps with macrophytes. In Violettes, TSV was high (between 80 and $280 \mathrm{~cm}^{3}$, with a mean of $206 \pm 68 \mathrm{~cm}^{3}$ ) and significantly higher with macrophytes than in the control traps on all four dates (Kruskal-Wallis, $\mathrm{p}=0.019$ ). Conversely, in Petit Hermitage, TSV was generally low (between 20 and $150 \mathrm{~cm}^{3}$, with a mean of $62 \pm 39 \mathrm{~cm}^{3}$ ) and significantly higher in the control traps than with macrophytes on three dates (KruskalWallis, $\mathrm{p}=0.025)$. In this slow flowing stream we observed very fine particles trapped inside the artificial macrophytes (on the surface of the plastic leaves) that did not fall inside the traps.

Table 3. Percentage of velocity decrease (\%) between the surface and bottom of stream water in Moulinet, Violettes and Petit Hermitage streams in April 2007 (mean \pm standard deviation of the replicates).

Tableau 3. Pourcentage de décroissance de la vitesse (\%) entre la surface de l'eau et le fond des ruisseaux Moulinet, Violettes et Petit Hermitage en avril 2007 (moyenne \pm écart-type des réplicas).

\begin{tabular}{|c|c|c|c|c|}
\hline Dates & Experimental conditions & & velocity de & \\
\hline \multirow{3}{*}{3 April } & & Moulinet & Violettes & Petit Hermitage \\
\hline & Control & $20.0 \pm 0.3$ & $41.4 \pm 0.2$ & $43.2 \pm 0.4$ \\
\hline & With macrophytes & $89.5 \pm 0.1$ & $89.0 \pm 0.1$ & $97.3 \pm 0.1$ \\
\hline \multirow{2}{*}{10 April } & Control & $43.9 \pm 0.1$ & $70.5 \pm 0.2$ & $26.8 \pm 0.1$ \\
\hline & With macrophytes & $92.9 \pm 0.1$ & $91.4 \pm 0.1$ & $100 \pm 0.1$ \\
\hline \multirow{2}{*}{17 April } & Control & $39.9 \pm 0.3$ & $42.8 \pm 0.1$ & $40.7 \pm 0.2$ \\
\hline & With macrophytes & $100 \pm 0.1$ & $78.8 \pm 0.2$ & $100 \pm 0.1$ \\
\hline \multirow{2}{*}{24 April } & Control & $39.4 \pm 0.3$ & $43.6 \pm 0.1$ & $18.5 \pm 0.1$ \\
\hline & With macrophytes & $98.8 \pm 0.1$ & $89.9 \pm 0.1$ & $100 \pm 0.1$ \\
\hline
\end{tabular}

Table 4. Sediment volumes $\left(\mathrm{cm}^{3}\right)$ collected from Moulinet, Violettes and Petit Hermitage streams during April 2007. Mean \pm standard deviation of the replicates.

Tableau 4. Volumes de sédiments $\left(\mathrm{cm}^{3}\right)$ collectés dans les ruisseaux Moulinet, Violettes et Petit Hermitage en avril 2007. Moyenne \pm écart-type des réplicas.

\begin{tabular}{lccc}
\hline Streams & Dates & \multicolumn{2}{c}{ Sediment volume $\left(\mathbf{c m}^{3}\right)$} \\
\hline & & Control & With macrophytes \\
\cline { 2 - 4 } Moulinet & 3 April & $135.6 \pm 36.1$ & $157.3 \pm 84.1$ \\
& 10 April & $147.9 \pm 122.7$ & $205.4 \pm 133.8$ \\
& 17 April & $168.6 \pm 49.4$ & $152.6 \pm 34.3$ \\
& 24 April & $199.7 \pm 31.8$ & $130.0 \pm 15.7$ \\
Violettes & & \\
& 3 April & $82.9 \pm 7.1$ & $178.9 \pm 30.5^{* *}$ \\
& 10 April & $202.5 \pm 72.5$ & $282.6 \pm 0.0^{* * a}$ \\
& 17 April & $179.9 \pm 18.8$ & $265.6 \pm 29.4^{* *}$ \\
Petit Hermitage & 24 April & $143.2 \pm 12.7$ & $265.6 \pm 15.7^{* *}$ \\
& & & \\
& 3 April & $66.9 \pm 20.8$ & $151.7 \pm 36.8^{* *}$ \\
& 10 April & $119.4 \pm 26.3$ & $34.9 \pm 7.1^{*}$ \\
& 17 April & $73.0 \pm 25.6$ & $37.7 \pm 21.4^{*}$ \\
& 24 April & $64.5 \pm 23.0$ & $37.2 \pm 20.4^{*}$ \\
\hline
\end{tabular}

a $282.6 \mathrm{~cm}^{3}$ is a full trap

${ }^{*} \mathrm{p}<0.05,{ }^{* *} \mathrm{p}<0.01$ : significant differences between control trap and trap with macrophytes 


\subsection{Quality of trapped sediments}

For the three streams, no significant changes in grain size characteristics were observed between dates, but differences were observed between streams (Kruskal-Wallis, $\mathrm{p}=0.018$; Figure 5). In Moulinet, the trapped sediments were dominated by gravels and coarse sand for the two experimental conditions ( $81 \pm 20 \%$ for control, and $77 \pm 22 \%$ with macrophytes). In Violettes, the sediments of the control traps were strongly dominated by gravels and coarse sand $(68 \pm 25 \%)$, whereas the sediments in the presence of macrophytes were dominated by gravels and coarse sand $(54 \pm 14 \%)$ and fine sand $(31 \pm 18 \%)$. Finally in Petit Hermitage, the sediments of the control traps were dominated by gravels and coarse sand $(74 \pm 20 \%)$, whereas the sediments in the presence of macrophytes were strongly dominated by fine sand $(58 \pm 24 \%)$. Silt and clay did not vary significantly among all the experimental conditions.

TOM percentage was higher in Petit Hermitage ( $47 \pm 16 \%)$ than in Violettes $(14 \pm 5 \%)$ and Moulinet $(5 \pm 2 \%$; KruskalWallis, $\mathrm{p}<0.05)$ but varied little during the month in the three streams (Friedman test, $\mathrm{p}>0.05$; Figure 6). TOM percentage was significantly higher in traps downstream from artificial macrophytes than in the control traps in Violettes on 17 and 24 April (Wilcoxon test, $\mathrm{p}<0.05$ ) and greatly enhanced at all dates in Petit Hermitage (up to eight times higher; Wilcoxon, $\mathrm{p}<0.05$ ), while the TOM contents were similar among experimental conditions in Moulinet (Figure 6).
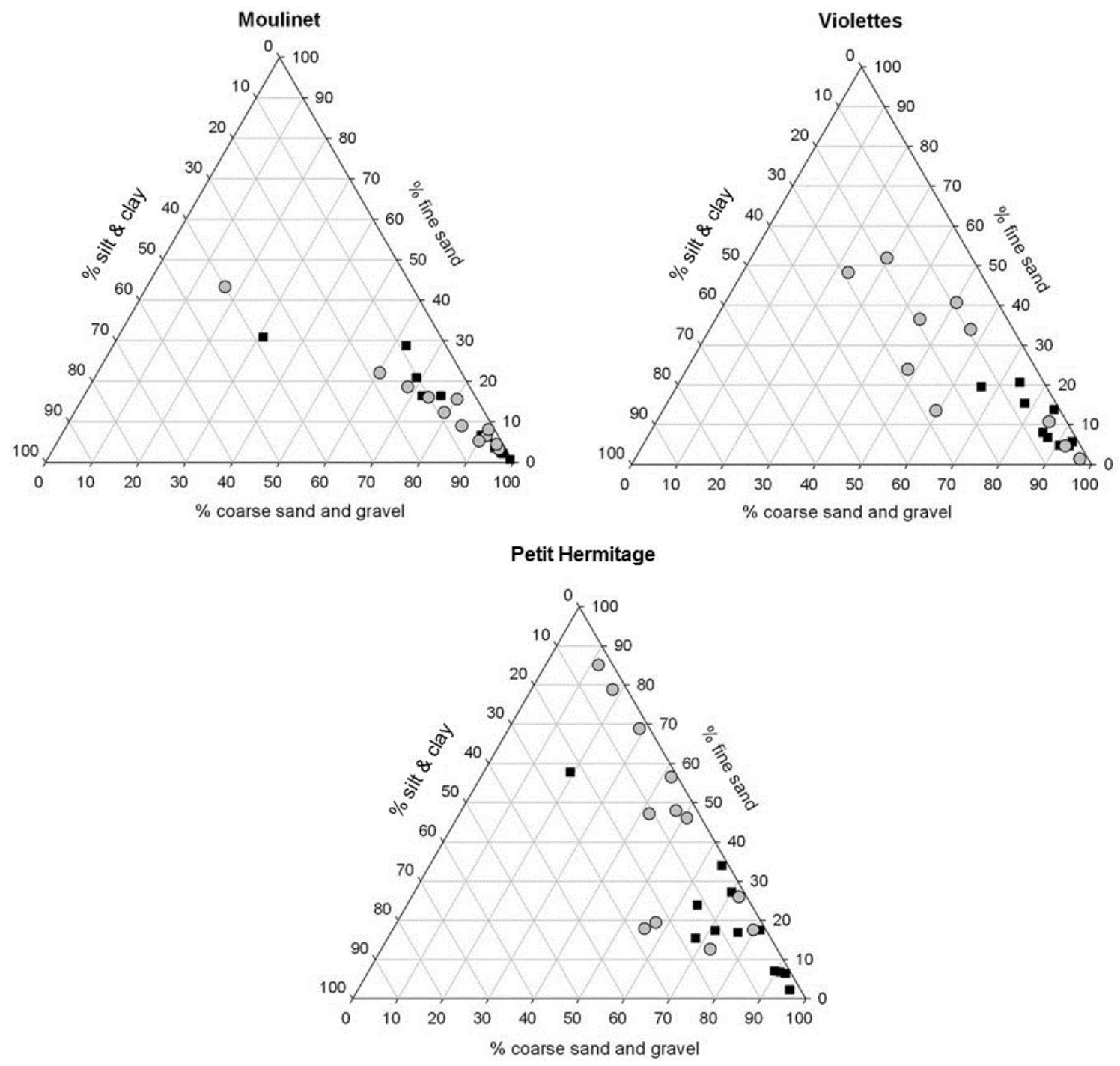

Figure 5. Ternary diagram with grain size composition of sediment collected in the Moulinet, Violettes and Petit Hermitage streams in April 2007. Each symbol represents a sample (black squares: control, grey circles: traps with macrophytes).

Diagramme ternaire de la composition granulométrique des sédiments collectés dans les ruisseaux Moulinet, Violettes et Petit Hermitage en avril 2007. Chaque symbole représente un échantillon (carrés noirs : contrôle; cercles gris : avec macrophytes) 


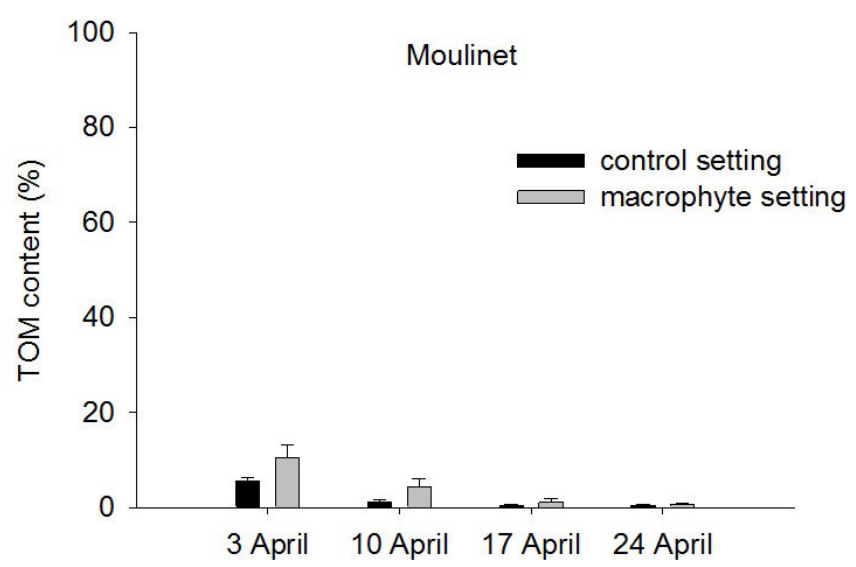

3.5 Statistical relationships between hydrodynamic variables and sediment characteristics

Significant negative correlations ( $\mathrm{r}$ around 0.4; $\mathrm{p}<0.05$ ) were observed between mean $\mathrm{Q}_{\mathrm{w}}$ and the fine sedimentary content (fine sand and silt \& clay) and also TOM content for traps located downstream from the artificial macrophytes and, to a lesser extent, for control traps (Table 5). In contrast, the gravel and coarse sand sampled in all types of traps were not related to $\mathrm{Q}_{\mathrm{w}}$.

Significant positive correlations ( $\mathrm{r}$ around $0.4 ; \mathrm{p}<0.01$ ) were observed between mean $\mathrm{Q}_{\mathrm{s}}$ and fine particle contents (fine sand and silt \& clay) for all experimental conditions, with similar values of $r$ for control and macrophytes settings (Table 5). The gravel and coarse sand sampled in all types of traps were not related to $\mathrm{Q}_{s}$.

Re was negatively correlated with TSV without $(r=-0.59)$ or with macrophytes $(r=0.61)$. When the turbulence produced by the macrophytes or the streambed increased, the amount of trapped sediments decreased. Re was positively correlated with the proportion of total coarse sediments ( $\mathrm{r}$ around 0.5 with or without macrophytes) and negatively correlated with the fine sediments (fine sand and silt \& clay). These two last correlations were higher in the presence of macrophytes ( $\mathrm{r}$ around 0.65 ).

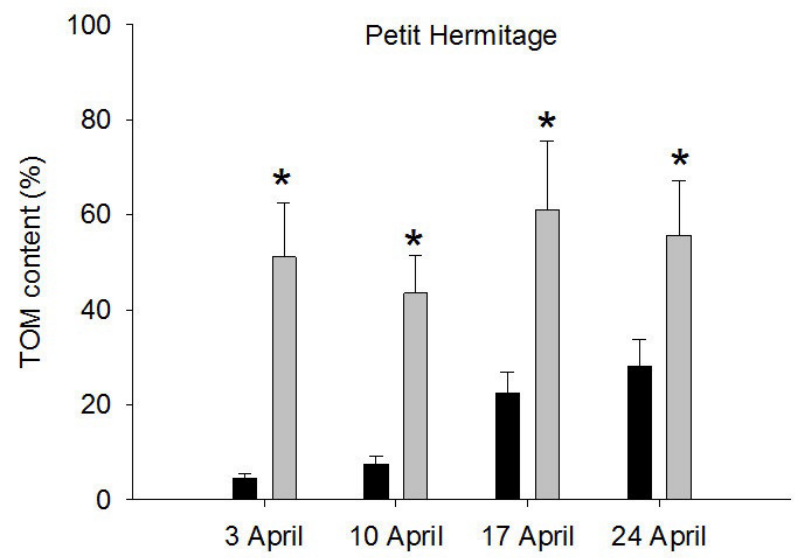

\section{DISCUSSION}

This work contributes valuable complementary results about the changes in hydraulic characteristics of water flow inside macrophyte stands, their effects on sedimentation, and the quantity and quality of the trapped sediments.

\subsection{Evaluation of the experimental method}

Figure 6. Total organic matter (TOM) content in sediment collected from the Moulinet, Violettes and Petit Hermitage streams in April 2007. Significant differences between control traps and traps with macrophytes $(\mathrm{p}<0.001)$ are represented by an asterisk.

Contenu en matière organique totale (MOT) des sédiments collectés dans les ruisseaux Moulinet, Violettes et Petit Hermitage en avril 2007. Les différences significatives entre pièges contrôles et pièges avec macrophytes $(p<0.001)$ sont représentées par un astérisque.

It is generally agreed that sediment traps are the most efficient method to measure settling fluxes with reasonable instrumental errors (BLOESCH and BURNS, 1979; GARDNER, 1985; GUST et al., 1996; HARGRAVE and BURNS, 1979; PALMER et al., 2004). Cylinder traps with a small opening mouth were used because, according to the detailed experiments of GARDNER (1980), their collection rate is the closest to the accumulation rate of sediments on the stream bed. 
Table 5. Spearman rank correlation (r) between total trapped sediment volume (TSV), each size class, percentage of total organic matter (TOM) and weekly mean discharge $\left(Q_{w}, N=36\right)$, weekly mean suspended sediment discharge $(\mathrm{Q}, \mathrm{N}=24)$, Reynolds number (Re; $\mathrm{N}=24)$.

Tableau 5. Corrélation de Spearman (r) entre le volume total des sédiments piégés (TSV), chaque classe granulométrique, le pourcentage de matière organique totale $(T O M)$ et le débit moyen bebdomadaire $\left(Q_{w}, N=36\right)$, l'apport moyen hebdomadaire de matières en suspension $(Q, N=24)$, le nombre de Reynolds (Re; $N=24)$.

\begin{tabular}{lcccccc}
\hline & & \multicolumn{3}{c}{$\mathbf{r}$} \\
\cline { 3 - 7 } & & TSV & $\begin{array}{c}\text { \% Coarse } \\
\text { sand \& gravel }\end{array}$ & \% Fine sand & \% Silt \& clay & \% TOM \\
\hline Without & Weekly mean Qw & -0.23 & -0.13 & $-0.42^{*}$ & -0.28 & -0.37 \\
macrophytes & Weekly mean Qs & 0.22 & -0.01 & $0.43^{*}$ & $0.45^{*}$ & 0.32 \\
& Re & $-0.59^{* *}$ & $0.42^{*}$ & $-0.41^{*}$ & $-0.48^{*}$ & $-0.54^{* *}$ \\
With & & & & & $-0.41^{*}$ & $-0.46^{*}$ \\
macrophytes & Weekly mean Qw & -0.21 & -0.03 & $-0.44^{*}$ & $0.37^{*}$ & 0.33 \\
& Weekly mean Qs & 0.17 & 0.01 & $0.41^{*}$ & & $-0.61^{* *}$ \\
\hline
\end{tabular}

${ }^{*} \mathrm{p}<0.05,{ }^{* *} \mathrm{p}<0.01$

The use of artificial macrophytes is not common and could raise concerns regarding the interpretation of results. However, using artificial plants rather than transplanting living macrophytes into the flume or the streams makes it possible to control the shape and size of the bundles and to avoid all the biochemical processes (e.g. root exudation or plant litter production), which could have an effect on sediment quality (COOPER et al., 2007; SAND-JENSEN, 2003). Several preliminary tests were carried out with different types of plastic vegetation in order to approach the shape and flexibility of Callitriche sp. stands, whereas previous studies used simple plastic tubes. The behaviour of our plastic macrophytes within the flow fulfilled our expectations. For example, there was an empty space between the overhanging canopy and the sediments in the downstream part of the stands, similar to Callitriche sp. bundles in natural streams. Also, coating microalgae developed on the artificial macrophytes leaves, and invertebrate organisms used them as a habitat, revealing their good imitation potential.

\subsection{Effect of macrophytes on flow characteristics}

Similarly to previous experiments conducted in flumes (SAND-JENSEN, 1998; SAND JENSEN and MEBUS, 1996; SAND-JENSEN and PEDERSEN, 1999), our in situ experiments showed evidence of a strong water velocity reduction downstream from macrophyte stands, represented by contrasting results between control traps and traps with macrophytes in the three streams. The complex spatial distribution of roughness elements within plant stands, stream bed and banks, and the shifting acceleration and slowdown of the flow outside and inside plant canopies, resulted in variable velocity profiles in Moulinet, Violettes and Petit Hermitage. The logarithmic shape of the flow velocity profile in the presence of emergent macrophytes is easy to reproduce in hydraulic flumes (SAND-JENSEN, 1998; SAND JENSEN and MEBUS, 1996; SAND-JENSEN and PEDERSEN, 1999), i.e. with uniform conditions of flow, stream morphometry, macrophyte characteristics and boundary layer. In natural rivers, such as in our experiment, velocity profiles are widely variable and different profiles can be observed (GHISALBERTI and NEPF, 2002; 2004; STONE and SHEN, 2002). The sigmoid shape, typical of submerged macrophytes with leaves and stems located in the middle depth (CAROLLO et al., 2002; GHISALBERTI and NEPF, 2002), was well identified in Moulinet, which is deeper and subject to higher velocities than the other two streams. A perfect logarithmic shape was only obtained occasionally in Violettes, but without macrophytes, suggesting that bottom roughness may also result in an efficient velocity decrease of the current in such shallow streams. Even if the most recurrent velocity profile shape (with or without macrophytes) was linear, all the shapes were associated to equivalent rates of velocity decrease between the surface and the bottom of the streams ( $80 \%$ to $100 \%)$. However, all these shapes may not lead to equivalent rates of sedimentation and this will be discussed further in the next section.

\subsection{Effect of macrophytes on sediment deposition}

Few studies have described the mechanism of re-suspension in macrophyte-dominated environments, and they generally focus on marine environments, wetlands and lakes (reviewed in MADSEN et al., 2001). Our experimental study showed that macrophyte stands similar to Callitriche sp. tend to intercept finer particles in small low-flowing streams such as Violettes and Petit Hermitage, which is consistent with 
SAND-JENSEN and PEDERSEN's (1999) observations in five small Danish streams. This result is crucial, given that clogging of the hyporheic zone is mostly due to silts and clays (WOOD and ARMITAGE, 1997). Sediment texture is also an important parameter in organic matter retention: the finer it is, the more organic matter is incorporated into the sediments (CHAMBERS et al., 1992; PARR and MASON, 2004) and becomes available for microbial community metabolism.

The mean $\mathrm{V}_{\mathrm{i}}$ values in April were similar in Moulinet and Violettes (around $0.5 \mathrm{~m} \cdot \mathrm{s}^{-1}$ ) but macrophyte stands showed greater efficiency in trapping sediments in Violettes when considering both TSV and the volume of fine sediments. Violettes is shallower, implying a macrophyte area/water column area ratio that is higher than in Moulinet. Considering the hydrodynamic characteristics that were also significantly different between these two streams, this suggests that a shallower water column may be more easily associated with a linear or logarithmic profile, which seems more effective for trapping particles than a sigmoidal profile. According to NADEN et al. (2006), the hydraulic resistance needed for a velocity decrease relates to boundary roughness, and implicitly assumes a logarithmic velocity profile. Thus, when the submersed macrophytes occupy the entire water column, sediments tend to accumulate. In contrast, when the water is deeper, the hydraulic resistance is less efficient and sediments tend to be re-suspended.

The Petit Hermitage is much slower and shallower than Moulinet and Violettes and the trapping experiment revealed a dissimilar sedimentation pattern. TSV with or without macrophytes were also much smaller but this result could be attributed to a SSC in water which was probably much lower (a mainly forested watershed and a very low discharge). Under such conditions, macrophytes did not increase total sediment retention in the traps, which was actually lower than the control. There was probably a lesser extent of coarse particles coming from the streambed by saltation and entering the trap. In this case, it appears that macrophytes act as a physical barrier against the settling particles. However, despite a lower total volume, the proportion of fine sand and organic fragments was much higher with macrophytes (including those on leaves). In this stream, macrophytes induced sorting between coarse and fine particles, a process that was less effective in the other two rivers.

We suppose that the contrasting results obtained between Moulinet and the other two streams may be linked to water velocities and resulting turbulence induced by the overall plant bed. Correlation analyses made between $\mathrm{Q}_{\mathrm{w}}, \mathrm{Q}_{\mathrm{s}}$, and the quantity and quality of sediments (Moulinet and Violettes data) allowed us to highlight that $\mathrm{Q}_{\mathrm{w}}$ and $\mathrm{Q}_{\mathrm{s}}$ determine the amount of fine sediments found in the traps, regardless of the presence or absence of macrophytes. However, this effect is surpassed when turbulence is high (higher velocity conditions), causing fewer fine particles to be trapped.

Water movement and sediment dynamics are also differently affected in and around submersed macrophyte beds. For example, when macrophytes are present in the streambed, they cause more chaotic water movement and the creation of vortices around the bundles, which tend to increase the re-suspension of fine sediments. However, this effect could be offset by the reduction of turbulence within large areas of macrophytes, and therefore by the accumulation of fine particles inside the macrophyte bed. These last observations highlight the variability at the macrophyte scale and the importance of the threshold values.

\subsection{Effect of macrophytes on organic matter trapping}

The percentage of TOM was much lower in streams located in agricultural areas than in Petit Hermitage, which is subject to allochthonous litter inputs coming from the surrounding forest. Particulate organic matter in Petit Hermitage consists of coarse particles such as leaves and twigs and fine organic particles, which are essential for both the interstitial fauna and the food web dynamics of the hyporheos. According to our results, the presence of broad-leaved macrophyte stands such as Callitriche sp. would greatly increase the accumulation of TOM in the benthic zone by physically intercepting these coarse particles within the foliage and making them available for shredders. These types of macrophytes have the same function as other retention structures such as large woody debris. Organic materials adsorbed onto fine particles such as clay would be more efficiently stored near macrophytes and may form biogeochemical and microbial process hotspots at the sediment water interface (CLARKE, 2002; PISCART et al., 2011). Fine particulate organic matter $(<1 \mathrm{~mm}$ in diameter), mainly in suspension, accounts for much of the downstream transport of organic matter in Moulinet and Violettes. According to the results observed in Violettes during the last two weeks of April, the low organic matter content in the benthic zone could be improved by the presence of macrophytes if discharge and depth conditions are optimal.

\section{CONCLUSION}

Brittany's low-order and agricultural streams have experienced a noticeable increase of sedimentation yield in the few years leading up to this study (LEFEBVRE et al., 2004). These changes may have long-term implications for the streams' ecological functioning and for the supply of ecosystem services. The role of macrophytes in particle retention is generally 
admitted but no general rules are available for the influence of stream characteristics at the local scale, such as mean flow or mean depth, on this ecosystem engineering role. In this paper, we suggest that submerged broad-leaved macrophytes such as the widespread Callitriche sp. have a stronger effect when the velocity can be significantly reduced, i.e. when the initial velocity is low (less than $0.5 \mathrm{~m} \cdot \mathrm{s}^{-1}$ ) and the depth shallow enough for the plant to occupy the entire volume of the water column. In such cases, macrophytes act as hotspots for sediments trapping and can locally reduce the clogging (by trapping fine particles) and modify the biogeochemistry of the hyporheic zone (by trapping coarse and fine organic matter). Conversely, turbulence prohibits high sedimentation rates and macrophyte stands may represent a physical barrier for fine particle deposition. Such information is essential to help the rehabilitation of some anthropologically altered streams, and to understand the environmental conditions in which macrophytes can reach sufficient abundance for their engineering roles.

\section{ACKNOWLEDGEMENTS}

This research was carried out with an interagency agreement between the "Unité Mixte de Recherche 6553 (Ecobio), Université de Rennes 1" and the "Unité Mixte de Recherche Ecologie et Santé des Ecosystèmes de l'Agrocampus de Rennes". Many thanks to Julien Tremblay and the "Unité Expérimentale d'Ecologie et d'Ecotoxicologie aquatique de l'Agrocampus" for their technical and field assistance.

\section{REFERENCES}

BLOESCH J. and N.M. BURNS (1979). A critical review of sedimentation trap technique. Aquat. Sci., 42, 15-55.

BIRGAND F., J.C. BENOIST, É. NOVINCE, N. GILLIET, P. SAINT-CAST and É. LE SAOS (2005). Mesure des débits à l'aide de débitmètres ultrasoniques Doppler - Cas des petit cours d'eau ruraux. Ingénieries, 41, 23-38.

BIRGAND F., J. LEFRANÇOIS, C. GRIMALDI, É. NOVINCE, N. GILLIET and C. GASCUEL-ODOUX (2004). Mesure des flux et échantillonnage des matières en suspension sur de petits cours d'eau. Ingénieries, 40, 21-35.

BRAMLEY R.G.V. and C.H. ROTH (2002). Land use effects on water quality in an intensively managed catchment in the Australian humid tropics. Mar. Freshwat. Res., 53, 931-940.
BRETSCHKO G. and M. LEICHTFRIED (1987). The determination of organic matter in river sediments. Arch. Hydrobiol. Suppl., 68, 403-417.

CAROLLO F.G., V. FERRO and D. TERMINI (2002). Flow velocity measurements in vegetated channels. J. Hydraul. Eng., 128, 664-673.

CHAMBERS P.A., E.E. PAS and K. GIBSON (1992). Temporal and spatial dynamics in riverbed chemistry: the influence of flow and sediment composition. Can. J. Fish. Aquat. Sci., 49, 2128-2140.

CLARKE S.J. (2002). Vegetation growth in rivers: influences upon sediment and nutrient dynamics. Prog. Phys. Geogr., 26, 159-172.

COLLINS A.L. and D.E. WALLING (2007). The storage and provenance of fine sediment on the channel bed of two contrasting lowland permeable catchments, UK. River Res. Appl., 23, 429-450.

COOPER G.G., E.M. CALLAGHAN, V.I. NIKORA, N. LAMOUROUX, B. STAZNER and P. SAGNES (2007). Effects of flume characteristics on the assessment of drag on flexible macrophytes and a rigid cylinder. New Zeal J. Mar. Fresh., 41, 129-135.

COTTON J. A., G. WHARTON, J.A.B. BASS, C.M. HEPPELL and R.S. WOTTON (2006). The effects of seasonal changes to in-stream vegetation cover on patterns of flow and accumulation of sediment. Geomorph., $77,320-334$.

DANIEL H. and J. HAURY (1996). Les macrophytes aquatiques : une métrique de l'environnement en rivière. Cybium, 20, 129-142.

FONSECA M.S. and J.A. CAHALAN (1992). A preliminary evaluation of wave attenuation by four species of seagrass. Estuarine Coastal Shelf. Sci., 35, 565-576.

GARDNER W.D. (1980). Sediment trap dynamics and calibration: a laboratory evaluation. J. Mar. Res., 38, 17-39.

GARDNER W.D. (1985). The effect of tilt on sediment trap efficiency. Deep Sea Res., 32, 349-361.

GAYRAUD S., E. HEROUIN and M. PHILIPPE (2001). Colmatage minéral du lit des cours d'eau : revue bibliographique des mécanismes et des conséquences sur les habitats et les peuplements de macroinvertébrés. Bull. Fr. Pêche Piscic., 365/366, 339-355. 
GHISALBERTI M. and H.M. NEPF (2002). Mixing layers and coherent structure in vegetated aquatic flows. J. Geophys. Res., 107, 3_1-3_11.

GHISALBERTI M. and H.M. NEPF (2004). The limited growth of vegetated shear layers. Water Resour. Res., 40, $1-12$.

GIBBS H., A. GURNELL, K. HEPPELL and K. SPENCER (2012). Macrophytes: ecosystem engineers in UK urban rivers. EGU General Assembly 2012, 22-27 April, Vienna, Austria, p. 490.

GREEN J.C. (2005). Modelling flow resistance in vegetated streams: review and development of new theory. Hydrol. Process., 19, 1245-1259.

GUST G., W. BOWLES, S. GIORDANO and M. HUTTEL (1996). Particle accumulation in a cylindrical sediment trap under laminar and turbulent steady flow: An experimental approach. Aquat. Sci., 58, 4297-326.

HAMILTON D.P. and S.F. MITCHELL (1996). An empirical model for sediment resuspension in shallow lakes. Hydrobiol., 317, 209-220.

HANCOCK P.J. (2002). Human impacts on streamgroundwater exchange zone. Environ. Manage., 29, 763-781.

HARDING J.S., E.F. BENFIELD, P.V. BOLSTAD, G.S. HELFMAN and E.B.D. JONES (1998). Stream biodiversity: The ghost of land use past. Proc. Natl. Acad. Sci. (USA), 95, 14843-14847.

HARGRAVE B.T. and N.M. BURNS (1979). Assessment of sediment trap collection efficiency. Limnol. Oceanogr., 24, 1124-1136.

HAURY J. and J.L. BAGLINIÈRE (1996). Les macrophytes, facteurs structurant de l'habitat piscicole en rivière à salmonides. Étude de microrépartition sur un secteur végétalisé du Scorff (Bretagne-Sud). Cybium, 20, 107-122.

HAURY J. and L. GOUESSE AÏDARA (1999). Quantifying macrophyte cover and standing crops in a river and its tributaries (Brittany, Northwestern France). Hydrobiol., $415,109-115$.

HEPPELL C.M., G. WHARTON, J.A.C. COTTON, J.A.B. BASS and S.E. ROBERTS (2009). Sediment storage in the shallow hyporeic of lowland vegetated river reaches. Hydrol. Process., 29, 2239-2251.
HORPPILA J. and L. NURMINEN (2003). Effects of submerged macrophytes on sediment resuspension and internal phosphorus loading in Lake Hiidenvesi (Southern Finland). Water Res., 37, 4468-4474.

KOSMAS C., N. DANALATOS, L.H. CAMMERAAT, M. CHABART, J. DIAMANTOPOULOS, R. FARAND, L. GUTIERREZ, A. JACOB, H. MARQUES, J. MARTINEZ-FERNANDEZ, A. MIZARA, N. MOUSTAKAS, J.M. NICOLAU, C. OLIVEROS, G. PINNA, R. PUDDU, J. PUIGDEFABREGAS, M. ROXO, A. SIMAO, G. STAMOU, N. TOMASI, D. USAI, and A. VACCA (1997). The effect of land use on runoff and soil erosion rates under Mediterranean conditions. Catena, 29, 45-59.

KOZERSKI H.P. and K. LEUSCHNER (1999). Plate sediment traps for slowly moving waters. Water Res., 33, 2913-2922.

KRISTENSEN P., M. SONDERGAARD and E. JEPPESEN (1992). Resuspension in a shallow eutrophic lake. Hydrobiol., 228, 101-109.

LEFEBVRE S. P. MARMONIER and G. PINAY (2004). Stream regulation and nitrogen dynamics in sediment interstices: comparison of natural and straightened sectors of a third order stream. River Res. Appl., 20, 499-512.

LEFRANÇOIS J., C. GRIMALDI, C. GASCUEL and N. GILLIET (2007). Suspended sediment dynamics on two small agricultural catchments: the bank degradation as a determinant factor. Hydrol. Process., 21, 2923-2933.

MADSEN J.D., P.A. CHAMBERS, W.J. JAMES, E.W. KOCH and D.F. WESTLAKE (2001). The interaction between water movement, sediment dynamics and submersed macrophytes. Hydrobiol., 444, 71-84.

NADEN P., P. RAMESHWARAN, O. MOUNTFORD and C. ROBERTSON (2006). The influence of macrophyte growth, typical of eutrophic conditions, on river flow velocities and turbulence production. Hydrol. Process., 20, 3915-3938.

NEPF H.M. (1999). Drag, turbulence, and diffusion in flow through emergent vegetation. Water Resour. Res., 35, 479-489.

PALMER M.R., H.M. NEPF and T.J.R. PEDERSEN (2004). Observations of particle capture on a cylindrical collector: Implications for particle accumulation and removal in aquatic systems. Limnol. Oceanogr., 49, 76-85. 
PARR L.B. and C.F. MASON (2004). Causes of low oxygen in a lowland, regulated eutrophic river in Eastern England. Sci. Total Environ., 321, 273-286.

PETTICREW E.L. and J. KALFF (1992). Water flow and clay retention in submerged macrophyte beds. Can. J. Fish. Aquat. Sci., 49, 2483-2489.

\section{PISCART C., S. NAVEL, C. MAAZOUZI, B. MONTUELLE,} J. CORNUT, F. MERMILLOD-BLONDIN, M.C. CREUZE DES CHATELLIERS, L. SIMON and P. MARMONIER (2011). Leaf litter recycling in benthic and hyporheic layers in agricultural streams with different types of land use. Sci. Total Environ., 409, 4373-4380.

SAND-JENSEN K. (1998). Influence of submerged macrophytes on sediment composition and near bed flow in lowland streams. Freshwater Biol., 39, 663-679.

SAND-JENSEN K. (2003). Drag and reconfiguration of freshwater macrophytes. Freshwater Biol., 48, 271-283.

SAND-JENSEN K. and J.R. MEBUS (1996). Fine scale patterns of water velocity within macrophyte patches in streams. Oikos, 76, 169-180.

SAND-JENSEN K. and O. PEDERSEN (1999). Velocity gradients and turbulence around macrophyte stands in streams. Freshwater Biol., 42, 315-328.
SCHULTZ M., H.P.KOZERSKI, T. PLUNTKE and K. RINKE (2003). The influence of macrophytes on sedimentation and nutrient retention in the lower River Spree (Germany). Water Res., 37, 569-578.

SMITH H.G. and D. DRAGOVICH (2008). Multi-scale sediment dynamics in an upland catchment, southeastern Australia: a synthesis. In: Sediment Dynamics in Changing Environments (Proceedings of a symposium held in Christchurch, New Zealand, December 2008), IAHS Publications, No. 325, pp. 291-297.

STONE B.M. and H.T. SHEN (2002). Hydraulic resistance of flow in channels with cylindrical roughness. J. Hydraul. Eng., 128, 500-506.

WHARTON G., J.A. COTTON, R.S. WOTTON, J.A.B. BASS, C.M. HEPPELL, M. TRIMMER, I.A. SANDERS and L.L. WARREN (2006). Macrophytes and suspension-feeding invertebrates modify flows and fine sediments in the Frome and Piddle Catchments, Dorset (UK). J. Hydrol., 330, 171-184.

WOOD P.J. and P.D. ARMITAGE (1997). Biological effects of fine sediment in the lotic environment. Environ. Manage., 21, 203-217. 